\title{
APLIKASI SISTEM PENJUALAN BARANG ELEKTRONIK MENGGUNAKAN METODE AUTHENTICATION CRYPTOSYSTEM MD5 PADA TOKO EDISON
}

\author{
${ }^{1}$ Samuel Martohap Purba, ${ }^{2}$ Nofita Rismawati, ${ }^{3}$ Rini Sriyanti \\ ${ }^{1,2,3}$ Teknik Informatika, Fakultas Teknik dan Ilmu Komputer, Universitas Indraprasta PGRI \\ Jalan Raya Tengah No 80, Kelurahan Gedong, Pasar Rebo, Jakarta Timur \\ 1.purbasamue196@gmail.com, 2novi.9001@gmail.com, $\underline{3}$ abib.arsyilla@yahoo.com
}

\begin{abstract}
ABSTRAK
Tujuan penelitian ini untuk membantu dalam proses penjualan barang,pembelian stok barang dan pengecekan stok barang.Dimana proses dilakukan secara digitalisasi untuk mempermudah dalam memonitoring setiap penjualan barang,pembelian stok barang dan pengecekan stok barang dapat lebih mudah dan efektif. Metode yang digunakan adalah waterfall pada sistem terkomputerisasi menggunakan Java Netbeans. Untuk analisis kebutuhan sistem menggunakan DFD (Data Flow Diagram) yang terdiri dari diagram konteks,rinci dan diagram yang diusulkan.Hasil dari penelitian yang dilakukan pada Toko Edison,aplikasi yang dikerjakan mampu mengatasi permasalah seperti penjualan barang,pembelian stok barang menjadi lebih tepat, cepat, efektif. Aplikasi yang dirancang ini mampu mengatasi permasalahan yang ada.
\end{abstract}

Kata Kunci: Barang Elektronik,Rancangan, Authentication cryptosystem MD5,DFD, MySQL

\begin{abstract}
The purpose of this research is to assist in the process of selling goods, purchasing stock of goods, and checking stock of goods Where the process is done digitally to make it easier to monitor every sale of goods, purchasing stock items and checking stock items can be easier and more effective. The method used is waterfall on a computerized system using Java Netbeans. For system requirements analysis using DFD (Data Flow Diagram) which consists of context diagrams, detailed and proposed diagrams. The results of the research conducted at the Edison Store, the application that was carried out was able to overcome problems such as selling goods, purchasing stock items to be more precise, fast, effective. This application is designed to be able to overcome the existing problems.
\end{abstract}

Key Word: Electronic Goods, Design, Authentication cryptosystem MD5, DFD, MySQL

\section{PENDAHULUAN}

Dalam perkembangan teknologi informasi saat ini memberikan banyak peluang untuk mengembangkan bisnis salah satunya adalah bisnis penjualan barang elektronik. Perkembangan teknologi yang didukung dengan perkembangan software maupun hardware yang semakin maju akan banyak membantu dalam mempermudah pengolahan data penjualan, pembelian barang dan persediaan barang. Sistem yang masih manual dan tidak terintegrasi dengan baik. hal ini dapat menyebabkan sering terjadi redudansi data sehingga data barang menjadi tidak dapat dikontrol dengan baik. Pencarian data stok barang masih sangat lama karena tidak adanya pengkodean pada setiap barang. Pembuatan laporan masih manual sehingga membutuhkan waktu yang lama. Pengecekan dan pembuatan laporan yang masih menggunakan cara manual kurang efektif.Dari permasalahan tersebut maka penulis membuat suatu aplikasi untuk membantu permasalahan yang ada.(Adi,widarma, 2017)

Menurut Hasan Abdurahman dan Asep Ririh Riswaya (2014),"aplikasi adalah program siap pakai yang dapat digunakan untuk menjalankan perintah-perintah dari pengguna aplikasi tersebut dengan tujuan mendapatkan hasil yang lebih akurat sesuai dengan tujuan pembuatan aplikasi tersebut, aplikasi mempunyai arti yaitu pemecahan masalah yang menggunakan salah satu teknik pemrosesan data aplikasi yang biasanya berpacu pada sebuah komputansi yang diinginkan atau diharapkan maupun pemrosesan data yang diharapkan. Pengertian aplikasi secara umum adalah alat terapan yang difungsikan secara khusus dan terpadu sesuai kemampuan yang dimilikinya, aplikasi merupakan suatu perangkat komputer yang siap pakai bagi user". 
Menurut Jogiyanto (2017 : 197) dalam jurnal menyatakan

bahwa "Perancangan sistem

adalah penggambaran, pembuatan sketsa dari beberapa eleme n yang terpisah dalam satu kesatuan yang ut uh dan berfungsi". (Yusuf, 2020) Message Digest 5(MD-5) adalah salah satu penggunaan fungsi hash satu arah yang paling banyak digunakan. MD-5 merupakan fungsi hash kelima yang dirancang oleh Ron Rivest yang didefinisikan pada RFC 1321. MD-5 merupakan pengembangan dari MD-4 (Iksan, Romli, Ikfal, 2018)

Menurut Sukamto dan Shalahuddin (2014:288). "Data Flow Diagram atau dalam bahasa Indonesia menjadi Diagram Alir Data (DAD) adalah refresentasi grafik yang menggambarkan aliran informasi dan transformasi informasi yang diaplikasikan sebagai data yang mengatur dari masukan (input) dan keluaran (output).

Peningkatan efsiensi dan efektifitas diperlukan dalam hal pengolahan data suatu transaksi dalam hal ini sepeti transaksi penjualan,transaksi pembelian stok barang dan pengecekan barang. Sistem yang digunakan pada saat ini masih menggunakan sistem manual yang rentan terhadap data yang kurang valid. Dalam hal ini dibutuhkan sistem yang dapat menyediakan laporan untuk setiap transaksi yang ada sehingga mempermudah dalam hal pengolahan data dan keakuratan data lebih aman.

Tujuan penelitian ini adalah Untuk menganalisis data barang mulai dari penjualan barang,pembelian barang dan pengecekan stok barang pada Toko Edison dan untuk menganalisis kesesuaian data laporan yang efektif dan akurat pada Toko Edison.

Manfaat penelitian ini memberikan sebuah aplikasi dapat membantu dalam hal penjualan barang elektronik dengan sebuah keamanan sistem yaitu MD5 (Message Digest 5).((Endang Setyawati, Carolina Ety Widjayanti, Ridho Ramadhan Siraiz, 2021)

\section{METODE PENELITIAN}

Metode yang dilakukan penulis adalah metode waterfall.(Hidayat et al., 2017)
Metode Waterfal salah satu jenis model pengembangan aplikasi dan termasuk kedalam classic life cyle (siklus hidup klasik), yangmana menekankan pada fase yang berurutan dan sistematis.untuk pemodelan pengembangannya, dapat dianalogikan seperti air terjun,dimana setiap tahapan dikerjakan secara berurut mulai dari atas hingga kebawah. Model ini melakukan pendekatan secara sistematis dan berurutan. Disebut waterfall karena tahap demi tahap yang dilalui harus menunggu selesai tahap sebelumnya dan berjalan berurutan. Metode pengumpulan data yang dilakukan penulis antara lain sebagai berikut :

\section{Studi pustaka ( Library research)}

Studi kepustakaan merupakan teknik pengumpulan data dengan tinjauan pustaka ke perpustakaan dan pengumpulan buku-buku, bahan-bahan tertulis serta referensi-referensi yang relevan dengan penelitian yang sedang dilakukan. Dalam hal ini penulis mengumpulkan informasi seperti penelitian sebelumnya baik yang itu skripsi dan jurnal yang dapat digunakan untuk menganalisis data dan fakta yang ada pada Toko Edison yang digunakan untuk penyelesaian penelitian ini.

Studi lapangan

a. Observasi

Hasil observasi tersebut dijelaskan dengan rinci, tepat, akurat, teliti, objektif, dan bermanfaat. Penelitian dilakukan langsung pada Toko Edison secara langsung dengan pemilik toko.

b. Wawancara

Metode wawancara merupakan bentuk komunikasi lisan yang dilakukan oleh beberapa orang secara langsung untuk mengumpulkan informasi tertentu. Dalam hal ini peneliti bertanya langsung dengan bapak selaku pemilik dari Toko Edison mengenai proses penjualan barang elektronik dalam hal ini pembelian, penjualan,pengecekan barang dan laporan.Wawancara dilakukan secara langsung dengan pemilik langsung dari Toko Edison.

Tempat penelitian pada toko Edison waktu penelitian dilaksanakan pada bulan MaretJuli 2021. 


\section{HASIL DAN PEMBAHASAN}

Analisis permasalahan

Sistem penjualan barang elektronik saat ini msih menggunakan sitem manual mulai dari penjualan barang, pembelian barang dan juga pengecekan barang yang masih dilakukan secara manual sehingga kemungkinan kesalahan bisa terjadi. (D. Tri Octafian, 2011) Dari pembahasan diatas penulis mengambil kesimpulan dan permasalahan yang ada diantaranya:

1. Untuk penjualan barang dan pembelian barang masih dilakukan secara manual sehingga ada kemungkinan kesalahan dalam hal penginputan data.

2. Pengecekan stok barang yang masih manual memakan waktu jika dilakukan pengecekan satu persatu barang.

3. Pembuatan laporan yang masih manual menggunkan kertas membuat lama dalam rekap data untuk semua data karena harus mencari semua berkas yang ada.

Berikut proses yang diusulkan untuk proses untuk pemecahan permasalahan yang ada.

1. Proses penginputan data

Pada proses ini penginputan data dilakukan oleh admin mulai dari data barang ,data konsumen,data suplier yang dilukan pada sistem.

2. Proses data

a. Proses pendataan barang

Admin melakukan pendatan untuk semua barang yanga ditoko yang direkap dalam sistem.

b. Proses pembelian stok

Admin melakukan pengecekan pada sistem yang yang dibuat kemudian membuat nota pembelian barang yang stok sudah habis atau berkurang.

c. Proses penjualan barang

Pada proses ini dilakukan oleh admin kemudian admin akan menginput data pada data penjualaan.

3. Proses laporan

Semua transaksi yang terdapat dalam sistem akan menghasilkan laporan seperti laporan penjualan,pembelian stok,laporan banyak transaksi dan laporan suplier yang diinput oleh admin kemudian akan diserahkan kepada pemilik toko dalam bentuk laporan.

\section{Dekomposisi sistem yang diusulkan}

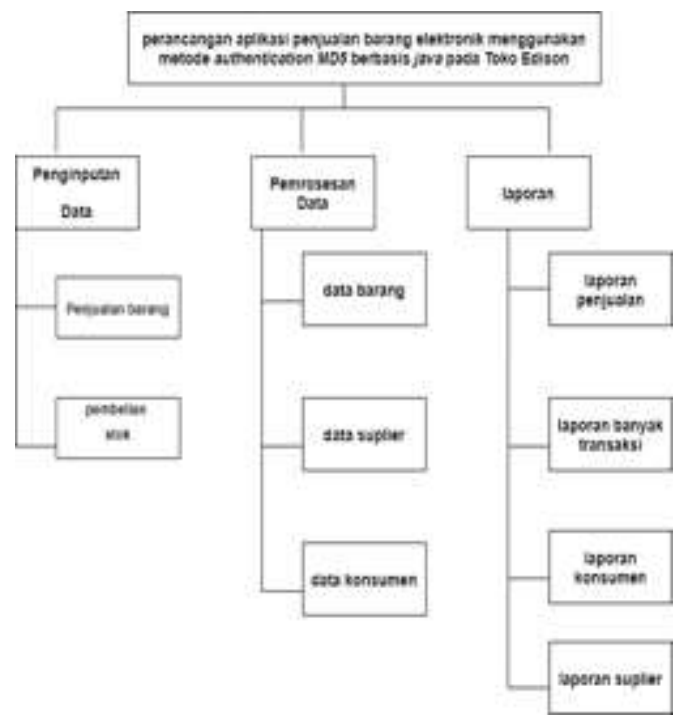

Gambar 1. Dekomposisi Fungsi yang Diusulkan

DFD (Data Flow Diagram) (konteks, Nol, Rinci) Sistem yang Diusulkan

DFD merupakan alat perancangan sistem yang berorientasi pada alur data dengan konsep dekomposisi dapat digunakan untuk penggambaran analisa maupun rancangan sistem yang mudah dikomunikasikan oleh profesional sistem kepada pemakai maupun pembuat program. (Dwi Purnomo, 2017)

a. Diagram konteks

Berikut ini adalah diagram konteks yang usulkan pada sistem yang akan dijalankan pada Toko Edison.

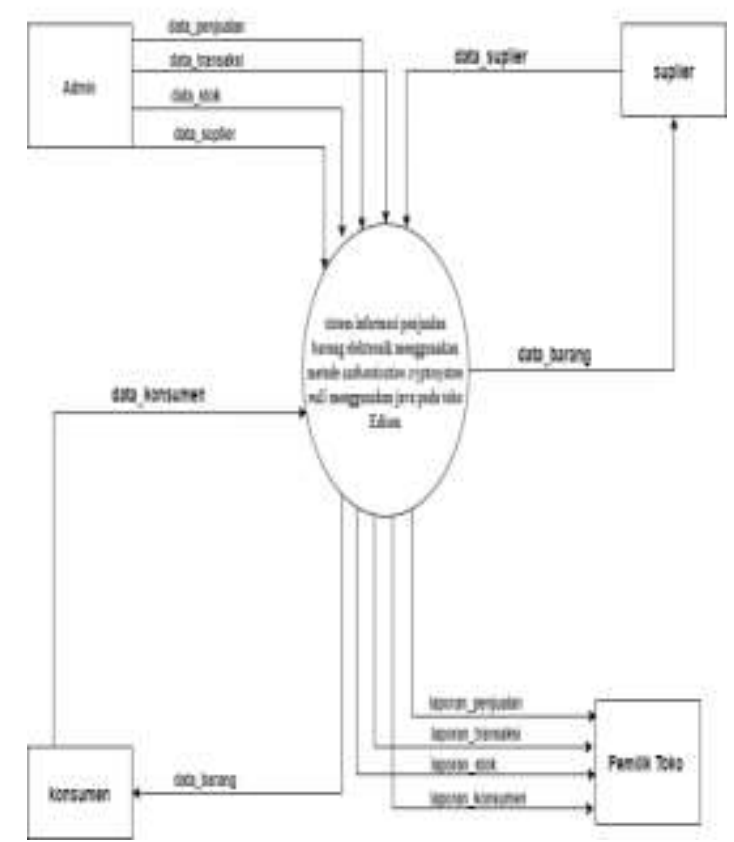

Gambar 2 Diagram Konteks yang Diusulkan 
b. Diagram Nol yang diusulkan Berikut merupakan diagram nol yang diusulkan pada Toko Edison

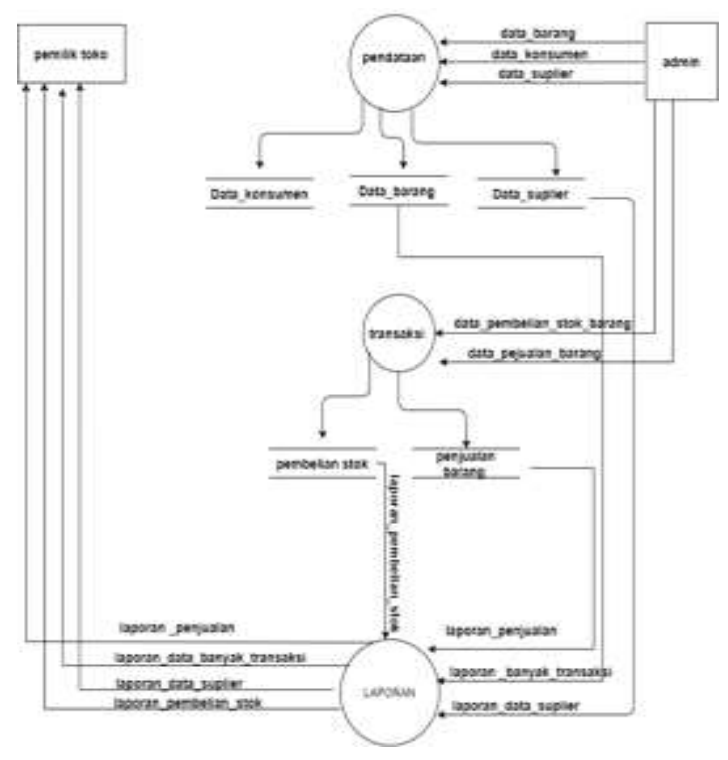

Gambar 3 Diagram Nol yang Diusulkan

c. Diagram rinci 1,2 dan 3 dari sistem yang diusulkan

1. Diagram rinci level 1

berikut ini diagram rinci level luntuk sistem yang diusulkan

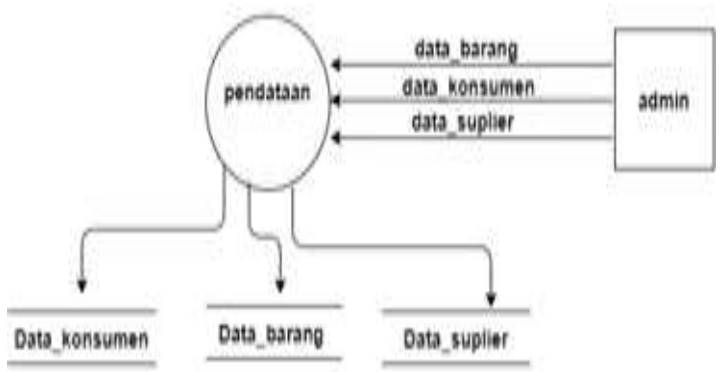

Gambar 4. Diagram Rinci Level 1

2. Diagram rinci level 2

Berikut ini merupakan diagram rinci level 2 dari sistem yang diusulkan

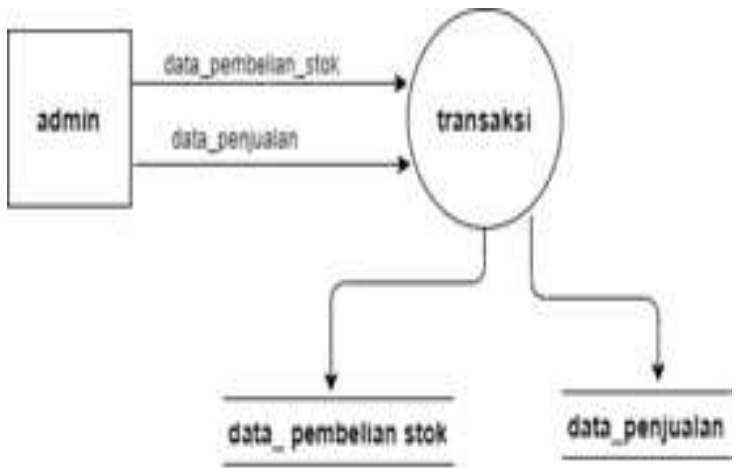

Gambar 5. Diagram Rinci level 2
3. Diagram rinci level 3

Berikut ini merupakan diagram rinci level 3 dari sistem yang diusulkan

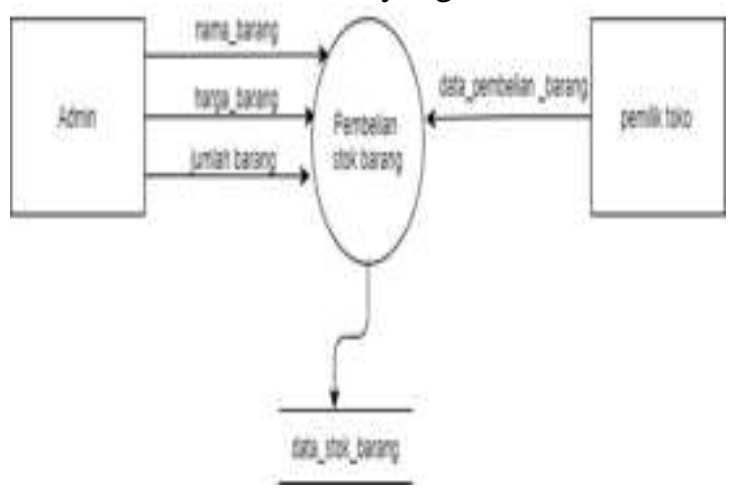

Gambar 6.Diagram Rinci Level 3

Basis data

Berikut ini merupakan basis data bentuk

\begin{tabular}{|c|c|c|}
\hline Id & to & id \\
\hline Nama & Tanggal pem belian & Nama \\
\hline Alamat & I0_mpliet & Email \\
\hline \multirow[t]{2}{*}{ No_tp } & I0_barang & Alamat \\
\hline & Quantity_tambah & No_tp \\
\hline Id & Harge_ttock & User_id \\
\hline Tangzal_penjualan & Total_harge_trock & \\
\hline Id_konsum en & Keterangan & \\
\hline \multicolumn{3}{|l|}{ 14_barang } \\
\hline \multicolumn{3}{|l|}{ Quantity_beli } \\
\hline \multicolumn{3}{|l|}{ Harge_barang } \\
\hline \multicolumn{3}{|l|}{ Total_hargs } \\
\hline \multicolumn{3}{|l|}{ Keterangan } \\
\hline \multicolumn{3}{|l|}{ Id } \\
\hline \multicolumn{3}{|l|}{ Nam a_barang } \\
\hline \multicolumn{3}{|l|}{ Stock } \\
\hline Harge_satuan & & \\
\hline
\end{tabular}

Gambar 7.Normalisasi Bentuk Unnormal

Normalisasi bentuk ke 1 (1NF)

Berikut ini merupakan normalisasi pertama dari bentuk unnormal

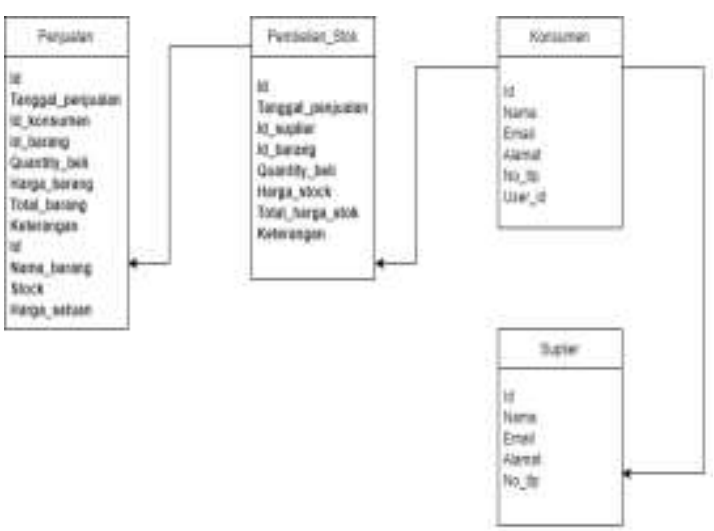

Gambar 8. Bentuk Normalisasi Ke 1(1NF) 
Normalisasi bentuk ke 2 (2NF)

Berikut ini merupakan normalisasi bentuk ke 2(2NF)

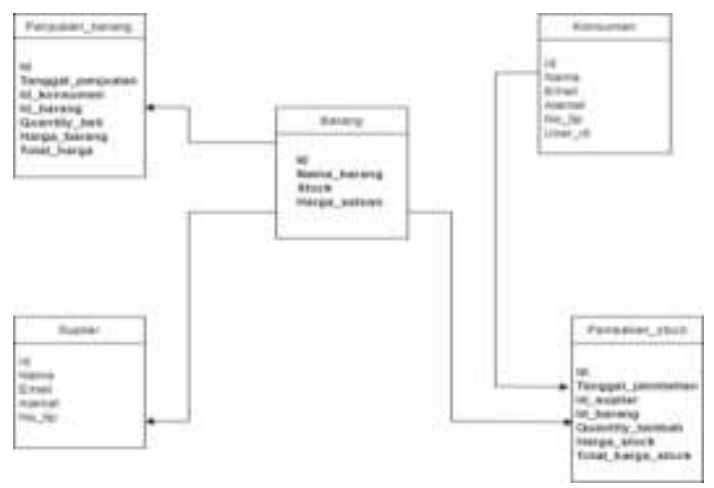

Gambar 9.Normalisasi Bentuk Ke 2 (2NF)

\section{ERD (Entity Relationship Diagram)}

Berikut ini merupakan ERD dari sistem yang akan diusulkan

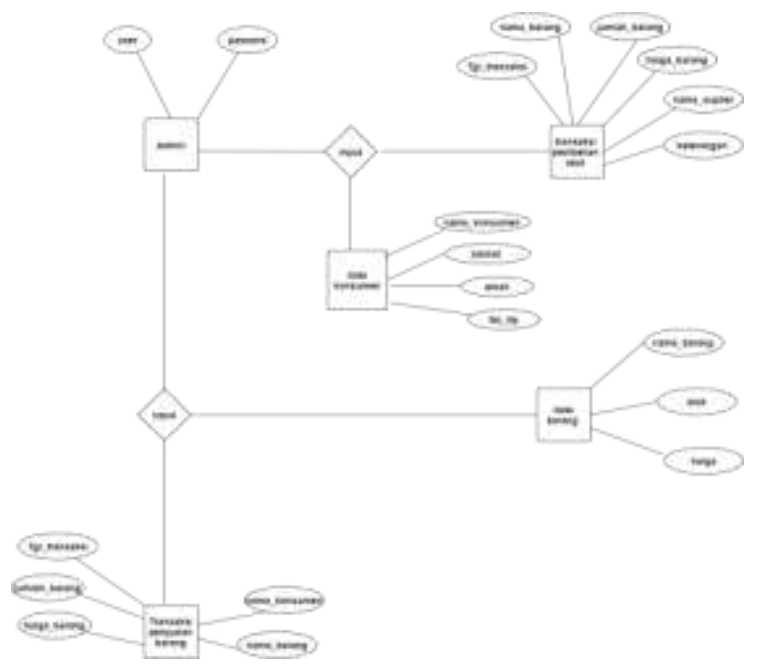

Gambar 10.ERD Sistem yang Diusulkan

\section{Rancangan form dan tampilan layar}

\section{Rancangan form login}

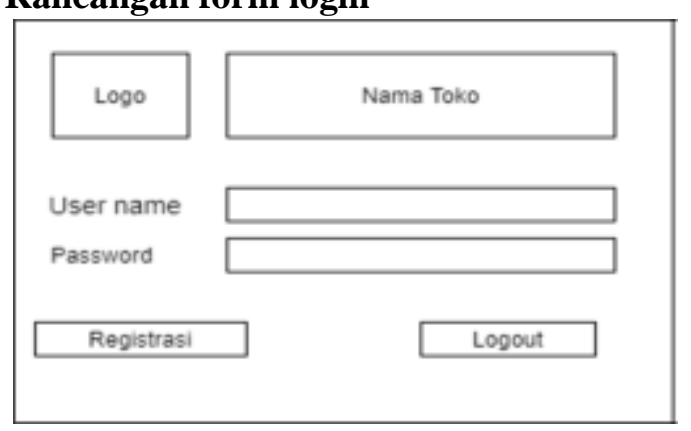

Gambar 11.Rancangan Layar Login

Tampilan merupakan rancangan form login yang terdiri dari logo,nama toko,user name,password,registrasi dan log out.

\section{Rancangan form menu utama}

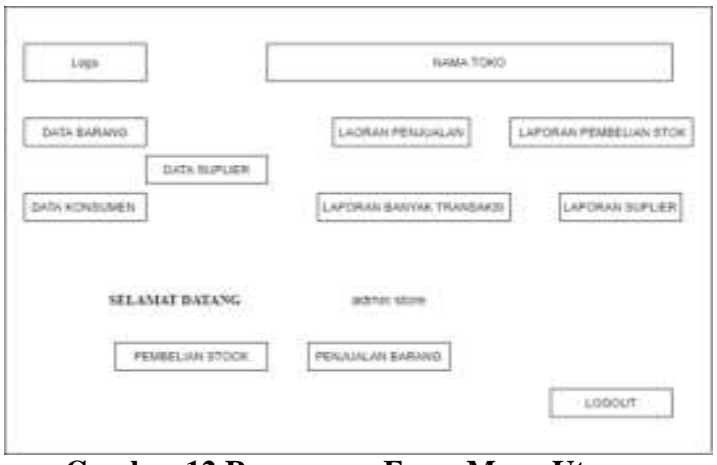

Gambar 12 Rancangan Form Menu Utama

Tampilan form diatas merupakanform dari ra ncangan layar form menu utama yang te rdiri logo, nama toko, form data barang, form data konsumen, form data suplier, pembelian stok,

penjualan barang, laporan banyak transaksi, laporan penjualan laporan pembelian stok, dan laporan suplier.

\section{Tampilan layar}

\section{Tampilan layar form login}

Berikut adalah tampilan layar untuk form login.

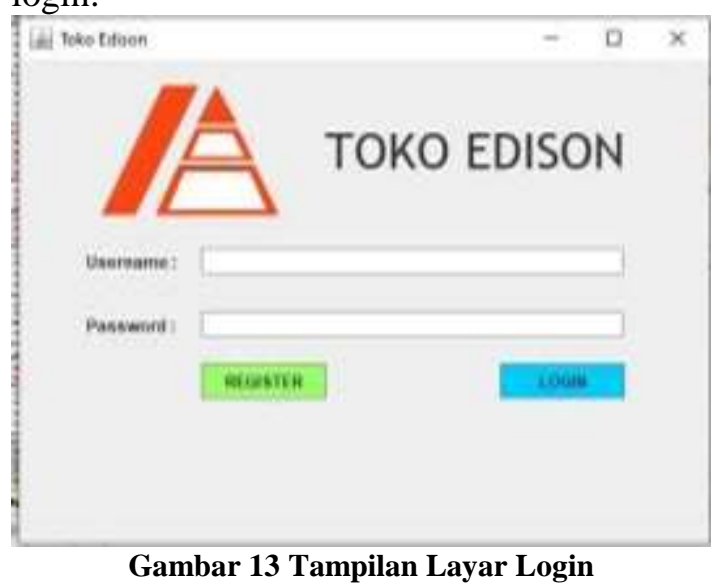

gambar diatas adalah tampilan awal dari program aplikasi untuk login menggunakan user name dan password.Jika user name benar maka proses login akan berhasil jika salah username dan password maka tidak akan berhasil login akan muncul username dan password salah.

\section{Tampilan layar menu utama}

Gambar 14 merupakan tampilan layar menu utama setalah login merupakan tampilan layar utamayang terdiri dari beberapa form seperti form data barang yang digunakan untuk menginput data, form data konsumen, form data suplier, form pembelian stok, form penjualan 
barang pada halaman ini juga terdapat for $m$ untuk laporan seperti form laporan pembelian stok, form laporan penjualan, form laporan banyak transaksi dan laporan suplier.

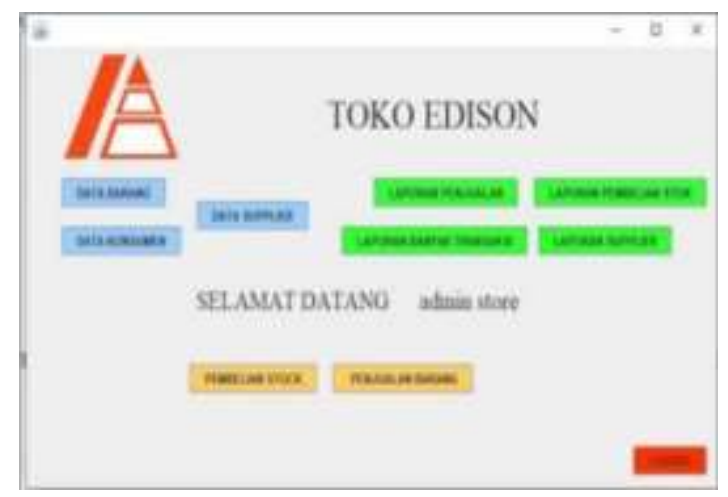

Gambar 14 Tampilan Layar Menu Utama

\section{Tampilan data barang}

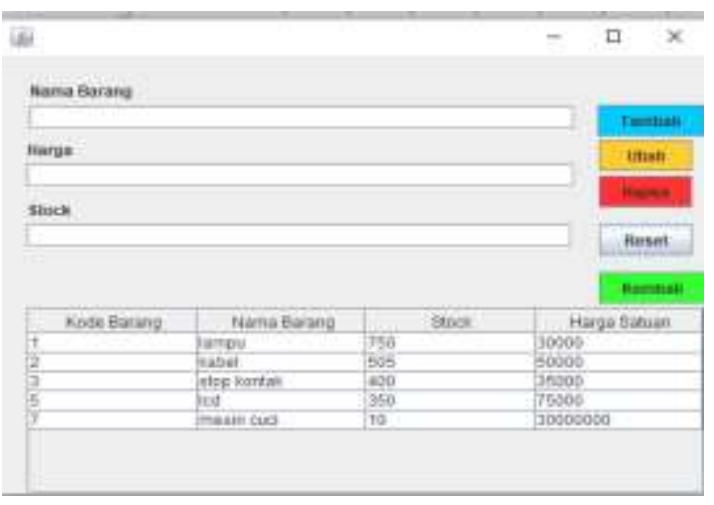

Gambar 15. Tampilan Data Barang

Pada tampilan ini untuk menginput data barang mulai dari nama barang,harga dan stok yang dilakukan oleh admin.

\section{Tampilan layar data konsumen}

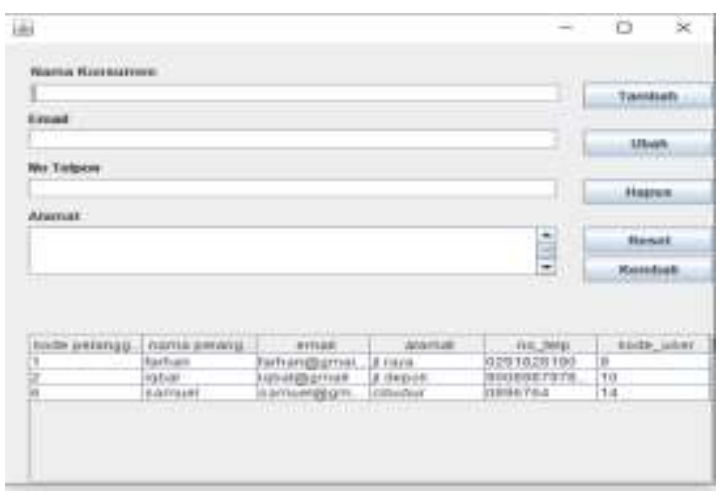

Gambar 16.Tampilan Layar Data Konsumen

Tampilan ini merupakan tampilan layar untuk data konsumen yang dapat dinput mulai dari nama,email,No.Telepon dan alamat.

\section{Tampilan layar data suplier}

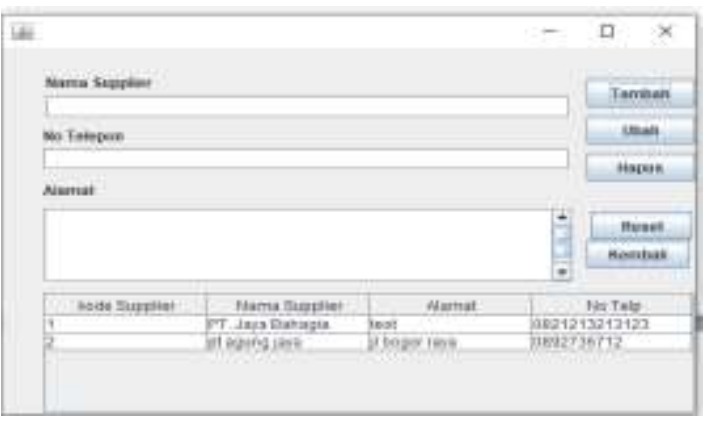

Gambar 16. Tampilan Layar Data Suplier

Pada form ini digunakan untuk menginput data suplier mulai dari nama suplier, No.telepon dan alamat.

\section{Tampilan layar pembelian stok}

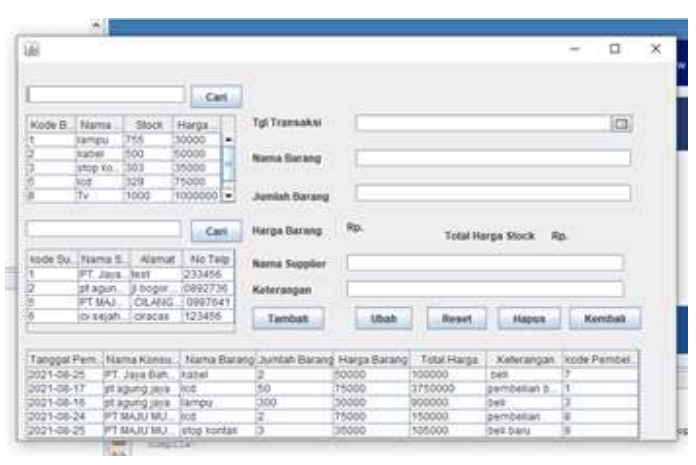

Gambar 17.Tampilan Layar Pembelian Stok

Pada tampilan ini untuk menginput data untuk setiap pembelian stok barang. Pada form ini di input mulai data barang,jumlah barang tanggal pembelian dan harga barang per satu barang.

\section{Tampilan layar data penjualan barang}

Tampilan ini digunakan untuk penginputan setiap ada transaksi penjualaan pada form ini diinput mulai dari tanggal transaksi,nama barang,jumlah barang, harga barang dan nama konsumen.

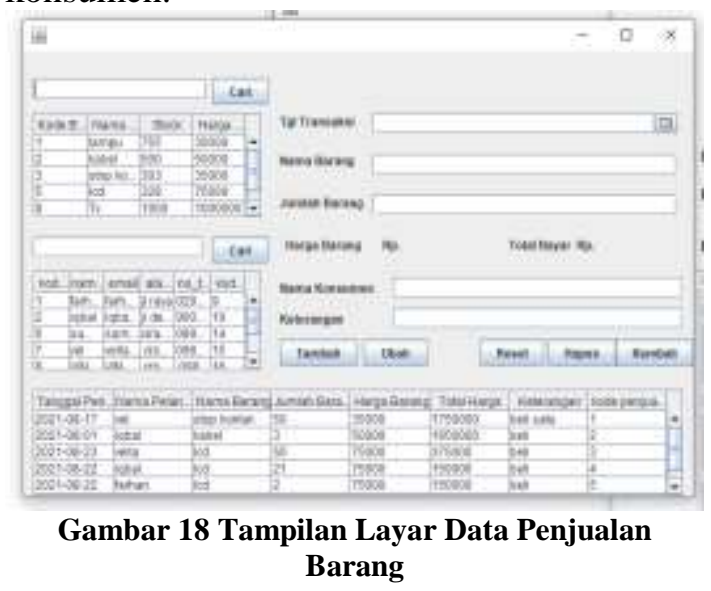




\section{SIMPULAN DAN SARAN}

Berdasarkan hasil analsis yang dibuat oleh peneliti maka simpulan dari penelitian tentang aplikasi penjualan barang elektronik menggunkan metode authentication cryptosystem MD5 berbasis java pada toko Edison maka ditarik simpulan sebagi berikut: Pembuatan rancangan sistem aplikasi penjualan dapat membantu pemilik toko dalam hal penjualan barang elektronik yang selama ini masih menggunakan cara manual kurang efektif dengan adanya aplikasi ini memudahkan dalam hal pendataan barang, pendataan konsumen, pendataan supplier. Pembelian stok dan penjualan barang juga lebih efektif dengan menggunakan sistem aplikasi dimana setiap transaksi akan mengasilkan laporan seperti laporan banyak transaksi, laporan data suplier, laporan pembelian stok barang dan laporan penjualan, Meminimalisir terjadinya kesalahan data akibat penulisan atau pembacaaan tulisan tangan sehingga proses pembuatan laporan dapat dilakukan dengan cepat dan akurat,Aplikasi yang dibuat menggunakan sistem keamanan yang dpat menjaga keamaan data dari pihak-pihak yang tidak bertanggung jawab, Penggunaan black box testing dipilih karena mempermudah dalam proses pembuatan enkrip data pada user.

Sejalan dengan perancangan aplikasi yang dibuat oleh penulis, maka demi tercapainya tujuan dan sasaran yang diharapkan, maka penulis dapat memberi saran sebagai berikut: rentan terhadap manipulasi data private key yang dibuat,diperlukan operator ahli untuk merawat atau menguasai masalahmasalah hardware maupun software agar terhindar dari masalah-masalah yang merugikan,hal yang dapat dilakukan untuk permasalah manipulasi yang terjadi perlu dilakukan pengembangan sistem kedapannya misalnya penambahan SHA1 atau SHA 56.

\section{DAFTAR PUSTAKA}

Adi,Widarma, S. R. (2017). Perancangan Aplikasi Gaji Karyawan Pada Pt. Pp London Sumatra Indonesia Tbk. Gunung Malayu Estate - Kabupaten Asahan. Jurnal Teknologi Informasi (Jurti), 1(2615-2738), 167. Http://Jurnal.Una.Ac.Id/Index.Php/Jurti/ Article/View/303/253\#

Afyenni, R. (2014). Perancangan Data Flow
Diagram Untuk Sistem Informasi Sekolah (Studi Kasus Pada Sma Pembangunan Laboratorium Unp. Jurnal Teknoif, 2.

D. Tri Octafian. (2011). Desain Database Sistem Informasi Penjualan Barang. Jurnal Teknologi Dan Informatika (Teknomatika), 1 No.2.

Dwi Purnomo. (2017). Model Prototyping Pada Pengembangan Sistem Informasi. Jimp - Jurnal Informatika Merdeka Pasuruan, 2 No.2(2503-1945).

Endang Setyawati, Carolina Ety Widjayanti, Ridho Ramadhan Siraiz, H. W. (2021). Pengujian Keamanan Komputer Kriptografi Pada Surat Elektronik Berbasis Website Dengan Enkripsi Metode Md5. Jurnal Manajemen Informatika Jayakarta, 1 No.1(27970930).

Hidayat, R., Marlina, S., \& Utami, L. D. (2017). Perancangan Sistem Informasi Penjualan Barang Handmade Berbasis Website Dengan Metode Waterfall. Simposium Nasional Ilmu Pengetahuan Dan Teknologi (Simnasiptek), 978-60261268-4-9.

Http://Seminar.Bsi.Ac.Id/Simnasiptek/In dex.Php/Simnasiptek2017/Article/View/138/138

Iksan, Romli, Ikfal, S. (2018). Sistem Informasi Pergudangan Pada Cv.Cokrodenganmodelpengembangan Sistem Waterfall. Sigma-Jurnal Teknologi Pelita Bangsa, 9(24073902407-3903).

https://www.jurnal.pelitabangsa.ac.id/in dex.php/sigma/article/view/468/283

Jogiyanto, H. (2017). Analisis dan Desain (Sistem Informasi Pendekatan Terstruktur Teori dan Praktek Aplikasi Bisnis) (Andi (ed.)). 20176/19.

Yusuf, K. (2020). Penerapan Algoritma Md5 Sebagai Pengaman Akun Pada Aplikasi Web Emusrenbang Kota Binjai. Jurnal Informatika Kaputama (JTIK), 4(5489704). 